\title{
Competitive Discourses among the Valencian Right Wing: Communication and strategy in the 2019 regional elections*
}

\author{
Adolfo Carratalá
}

UNIVERSITAT DE VALÈNCIA

adolfo.carratalađuuv.es

ORCID: 0000-0002-9865-9246

\section{Dolors Palau Sampio}

UNIVERSITAT DE VALÈNCIA

dolors.palaufauv.es

ORCID. 0000-0001-9051-0239

Received: 28/10/2019

Accepted: 25/03/2020

\begin{abstract}
The 2019 regional government election in The Valencian Country led to a new panorama on the Right. For the first time, there were three political parties competing for votes. In addition, the notoriety gained by the Far Right created a new political scene, posing a challenge to other parties. This paper analyses how the Partido Popular, Ciudadanos and Vox managed a campaign in which they were both electoral opponents but also potentially future parliamentary allies. The research examines the performance and campaign discourse of these three parties based on content analysis of the coverage of two newspapers' (Levante-EMV and Las Provincias). The study examines the preferred frames of reference, the main topics, the cultural resonances and the ideological frameworks chosen by these parties. The results showed that news on these parties stressed leadership style and strategy - issues that were highlighted in the parties' discourses given that they resonate strongly with Conservative voters. The issues chosen by the Far Right had little impact on the messages put over by the majority parties. The presence of three rightwing parties meant each tried to differentiate itself from the others. Vox [the farthest on the right, reminiscent of France's Front National] tried to distinguish itself from the more mainstream Partido Popular (PP), which in turn was forced to defend its position as the 'institutional' party of the right. Ciudadanos (Cs) was the right-wing party that spoke most often of potential co-operation among the three forces.
\end{abstract}

Keywords: Autonomous Community of Valencia, regional election, political discourse, media coverage, right-wing parties, framing.

\footnotetext{
*Acknowledgements: This study forms part of the R\&D project Estrategias, agendas y discursos en las cibercampañas electorales: medios de comunicación y ciudadanos [Strategies, agendas, and discourses in election cyber-campaigns: the media and citizens] (reference CS02016-77331-C2-1-R), awarded by Spain's Ministry for the Economy and Competitiveness (MEC) for the period 2017-2020.
} 
Corresponding author: Adolfo Carratalá. Departament de Teoria dels Llenguatges i Ciències de la Comunicació Facultat de Filologia, Traducció i Comunicació Avda. Blasco Ibáñez, 32 - 46010, Valencia (Spain).

Suggested citation: Carratalá, A. and Palau Sampio, D. (2020). Competitive Discourses among the Valencian Right Wing: Communication and strategy in the 2019 regional elections. Debats. Journal on Culture, Power and Society, 5, 125-143. DOI: http://doi.org/10.28939/iam.debats-en.2020-7

\section{INTRODUCTION}

The Valencian Regional Election held on the $28^{\text {th }}$ of April 2019 took place in a political context that was entirely new for Valencia's Centre-Right parties. For the first time since 1995, the main Conservative party in The Valencian Country -Partido Popular (PP) with Isabel Bonig as its presidential candidate - faced an election as Leader of The Opposition, after PSPV-PSOE and Compromís had cobbled together a coalition government during the previous legislature, with the parliamentary support of Unides Podem. It was also the first time that in the 'best case scenario', PP would have to strike a deal with two other Right-Wing parties if it wanted to form a new government and wrest power from the Opposition. The other two Right-Wing parties were: (1) Ciudadanos (which was running in a Valencian Regional Election for the second time after winning 13 seats in 2015); (2) Vox, which was running in the election for the first time, and was in with a chance of winning its first seats (the first time round in 2015 , it won no seats, polling only a paltry $0.41 \%$ of the votes cast $(10,184$ ballot papers).

The polls published in the run-up to the election forecast that the only chance of pushing the LeftWing three-party coalition out of Office would be to form a three-party Right-Wing coalition. Various opinion polls indicated that The Valencian Country might change political colour after the $28^{\text {th }}$ of April. One such poll was produced by SyM Consulting and published in Valencia Plaza newspaper on the $3^{\text {rd }}$ of February, forecasting that a PP-Cs-Vox coalition would win 54 seats out of a total of 99. A poll published by NC Report for La Razón newspaper forecast that the three Right-Wing parties might win 51 seats (an absolute majority, albeit by a whisker), which would be sufficient to invest a Conservative President.
These early polls were encouraging for the Centre-Right parties. The poll published by SyM Consulting for $\mathrm{Va}$ lencia Plaza put Partido Popular as the party enjoying the greatest electoral support in The Valencian Country, with the prospect of winning 23-24 seats. The same poll also rated Vox's prospects highly, forecasting it might get 14-15 seats. Even so, the Regional Election not only created uncertainty as to whether the Right would regain control of Valencia's Parliament but also revealed a battle between Ciudadanos and PP. Some polls even went so far as to suggest Ciudadanos might wrest the crown from PP as the party leading the Right-Wing of Valencia's political spectrum. A study carried out by Spain's Centre for Sociological Research (CIS) was published on the $11^{\text {th }}$ of April and left this possibility open, forecasting Ciudadanos would win $16-19$ seats (16\% of votes cast) and PP with $18-19$ seats (15.4\% of the vote). An IMPO Insights poll for COPE radio pointed in the same direction, forecasting that Ciudadanos would win 17 or 18 seats ( $16.5 \%$ of votes ) and that PP would win 16 seats (15.5\% of votes).

The scenario was thus one of great uncertainty both regarding whether the combined Centre-Right parties could beat the incumbent Centre-Left coalition, and which party among PP, Ciudadanos, and Vox would get the most seats. This study looks at how two of The Valencian Country's two main newspapers (and the biggest ones in the City of Valencia) - Levante-EMV and Las Provincias - covered the campaigns of these parties. To this end, we focused on the dominant frames in that coverage, the weight given to the historic Conservative discourse in The Valencian Country, and the extent to which each of these parties tried to position itself in the media with a view to clearly differentiating itself from the other two parties it was competing with for the Central-Right vote. 
To properly frame this study from a technical standpoint, one needs to examine the electoral activities of Centre-Right parties in Valencia from both diachronic and synchronic standpoints. The two following sections therefore examine: (1) Anti-Catalanism as the rhetorical key to parties in this part of the political spectrum since the times of the so-called 'Battle of Valencia' - an event that took place during Spain's rocky transition from dictatorship to democracy and in which the Valencian Far-Right played a key role; (2) the recent rise of the Far-Right in Europe and its growing influence on the discourse of hegemonic Central-Right parties. We shall then describe some of the key ideas on political communication during an election campaign. We also set out the methodological approach used in the study, our main findings, and the conclusions that can be drawn from our testing of the research hypotheses.

\section{THE RIGHT WING AND THE RADICALISATION OF POLITICAL DISCOURSE IN THE VALENCIAN COUNTRY}

Although no Far-Right party (such as Vox) gained parliamentary seats until 2019, the Far-Right's views and deeds have shaped the development of Valencia's Regional Government ever since the 1970s. The emergence of the 'identity conflict' during the years in which Spain transitioned from dictatorship to democracy constituted the so-called 'Battle of Valencia'. This was instigated by stalwarts of the Franco Regime, such as Miguel Ramón Izquierdo and Ignacio Carrau, Mayor of Valencia and President of the Diputación (Regional Board) up until the first municipal elections in 1979. The 'battle' marshalled a complex, reactionary alliance, bringing together political and socio-cultural interests (Junta Central Fallera, Lo Rat Penat, Academia de Cultura Valenciana), and the media (Las Provincias). The alliance's goal was to split the Valencian people and to lure part of the electorate to Far-Right positions" (Sanz, 1982: 76-77). This strategy was clearly evidenced by the positions the alliance shared with the regime towards the end of the Franco dictatorship. In drawing up the elements of regional identity in Valencia's Statute of Autonomy, the
Far-Right intervened in the political and social arena, tolerated and sponsored by the well-ensconced forces of reaction (Sanz, 1982; Cucó, 2002). The Statute of Autonomy determined the region's name, language, and flag. As Mira notes, "He who controls the content and meaning of the symbols used, and how they are disseminated and learnt also controls the awareness that stems from them" (1985: 29).

Historians such as Cucó have argued that calling "a singular, uncivil, undemocratic rebellion" 'The Battle of Valencia' is a misnomer because: “This 'battle' never took place [...]. It was a welter of deliberately-provoked violence that was almost always of a unilateral nature [...], marking a watershed that deeply scarred culture and democracy in The Valencian Country" (Cucó, 2002: 136). Albert and Hernàndez link this campaign of violence with "a strategy by the Far-Right after Franco's death to stop the advance of the Left-Wing in general and Left-Wing nationalists in particular" (2011: 6).

The clash was a way of watering down, if not wholly thwarting, aspirations for greater self-government (for which provision was made in Article 151 of Spain's new, post-dictatorship Constitution). Article 151 was applicable to Spain's historic nations. The politicisation of symbols, in particular anti-Catalanism, turned Article 151 into a tool of the UCD (Unión de Centro Democrático) and its leaders. The anti-Catalan strategy was seized upon as a pretext for thwarting progress towards self-government and, in the process, the advance of PSPV-PSOE as the party winning most votes in The Valencian Country (Sanz, 1982: 163). Picó and Reig blame UCD and its main leaders in Valencia for fuelling a "visceral, aggressive Valencianism" supporting all groups boycotting incipient democratic institutions, aided and abetted by "notorious Fascist groups". The aim was to shamelessly 'exploit' popular feeing against the supposed "Catalan peril" (1988: 958-961). In this context, a "socio-political movement" - blaverismo - turned anti-Catalanism into its raison d'être (Flor, 2009), wrapping it up in a travesty of "Valencian selfgovernment" which, in effect, "re-invented Valencian traditions and identity" (Flor, 2010: 113). 
Las Provincias newspaper and its then Deputy Director, María Consuelo Reyna, played key roles in "Blaverism's successful social penetration" (Flor, 2010: 121) in what Cucó termed the "neo-Fascist Populism" (1983: 84). The Right shamelessly banged on about the evils of regional autonomy as a way of drumming up votes. This political-media alliance (Xambó, 1995, 2001; Viadel, 2006; Iranzo, 2011) played a major role in 'The Battle of Valencia'. "Las Provincias, Reyna and gang turned anti-Catalanism into a crusade that threw journalistic ethics and rules to the winds, ruthlessly hounding public figures and providing an intellectual pretext for violence"(Viadel, 2006: 214).

Far from being limited to the realm of debate, the clash was "long, complex, virulent, the prosecution of a war" (Mollà and Mira, 1986: 157). There were many violent acts in the late 1970s and early 1980s, many of them attributed to Grupo de Acción Valencianista (GAV), which had links with the Far Right. Bombs were used against intellectuals such as Joan Fuster and Manuel Sanchis Guarner, attacks were made against those defending the unity of Catalan [of which Valencian is a dialect], and against Llibreria 3 i 4 [bookshop]. Threats and attacks were also made against staff at RTVE's [Spanish TV] Regional Centre in The Valencian Country, and there was street violence too. The strategy pursued by UCD and backed up by sections of the media and Right-Wing thugs sought to kill off any hopes of self-government. The goal was to make citizens drop their support for regional autonomy and negotiation with Spain's highly centralised national government" (Picó and Reig, 1988: 958-961). This dastardly plan succeeded.

\section{THE RISE OF THE FAR RIGHT EUROPE: MESSAGES AND IMPACTS}

Right now, Far-Right parties are waxing in many European countries and some are even in government. In Poland, for example, the Law and Justice Party (Prawo i Sprawiedliwość - PiS) won 37.6\% of the votes cast in the 2015 election. The Freedom Party of Austria (Freiheitliche Partei Österreichs - FPÖ) got $26.65 \%$ of the vote in the 2017 election, and Italy's Liga Norte won $17.4 \%$ of votes in the 2018 . All these parties formed part of the government in some shape or form. France's Front National (the second-biggest party in the 2017 election with $21.3 \%$ of the votes), the 'Movement for a Better Hungary' (Jobbik), got $19.1 \%$ of the vote in 2018), Denmark's People's Party (Dansk Folkeparti DF), got 21.1\% in 2015) and Germany's Alternative für Deutschland (AfD) won $12.6 \%$ of votes in 2017).

These are all examples of a re-birth of the Far Right in Europe over the last few years, although one should note that this growth has taken place over the last four decades. Since the early 1980s, a new Far Right began to rise in some Eastern European countries. Despite their marked ultra-nationalist natures, they eschewed Fascism and Nazism because they did not seek dissolution of institutions and democratic freedoms, despite their fierce criticism of the Welfare State and the defence of lower taxes (Rodríguez Jiménez, 2006). These parties, encouraged by the success of France's Front National, carved out a niche for themselves in their respective parliaments (De Lange, 2012), and also in the European Parliament, ever since Le Pen won ten MEPs in the 1984 elections (Gómez Reino, 2009). Since then, the Populist Far Right has become a major political player in Europe (Hernández Carr, 2011).

In great measure, this protagonism has been the result of an 'us and them' populist discourse designed to broadly appeal to Europeans. "Them" in this case comprises various groups that are tarred as a threat (Krasteva and Lazaridis, 2016). Immigrants have been one of the main targets of this strategy of constructing "the other". As Hernández Carr (2011), notes, antiimmigration xenophobia has become the launch pad for political mobilisation among the whole of Europe's radical, populist Far Right. This includes parties such as Alternative für Deutschland (AfD), which sprang into being with the sole aim of battling European Monetary Union in the midst of the Sovereign Debt Crisis. However, it soon shifted its discourse towards criticism of immigration, using xenophobic messages in its campaigns (Schmitt Beck, 2017). The anti-immigration discourse harped on diverse themes. Sometimes it was 
based on cultural racism; on others it linked immigration to terrorism (Pajnik, Fabbro and Kamenova, 2016). The latter theme helped Far Right parties come up with one of their main discursive ploys, namely anti-elitism, accusing 'the powers that be' of betraying those they were supposed to represent. Using this anti-establishment argument (Krasteva and Lazaridis, 2016), Far Right parties could pass themselves off as different from traditional ones and indeed, as 'super parties' seeking to represent the nation/folk that had been done down by those at the top (Antón Mellón and Hernández Carr, 2016).

Apart from immigrants, other targets of the Far Right's wrath are the elites, the LGTBI community, and 'gender politics'. Such parties stress the traditional family and women's role as mothers (Mayer, Šori and Sauer 2016). Although these parties deny homophobia and say they are in favour of equality between men and women (especially in countries such as Denmark and Norway), they oppose gender-equality policies, such as quotas and 'positive discrimination' measures. (Meret and Siim, 2013). Instead, they argue that LGTBI groups and feminist organisations are no more than lobbies and militant ideological movements that one needs to oppose (Mayer, Šori and Sauer 2016). Paradoxically, these parties also present themselves as great defenders of women and sexual minorities when it comes to attacking certain immigrant and religious communities (especially Muslim ones) for the latter's retrograde treatment of such groups (Meret and Siim, 2013).

The growth of Far-Right parties in European institutions has led to marked changes in the political landscape, especially in the position occupied by the Centre-Right. As De Lange (2012) notes, since the end of the 1990s most majority Conservative began to co-operate with radical Right-Wing parties in various national governments - something that occurred first in Italy and Austria and then, several years later, in Denmark, Norway, and The Netherlands. According to De Lange, this trend can be explained by majority parties' desire to attain the kind of power where they can put their policies into action. It was, he argues, also part of a strategy to neutralise the Far Right, which had begun to win more and more votes and posed an ever greater threat as a political opponent. The upshot was growing bipolarisation of national politics and an increasing drift to the right in Conservative parties on issues such as culture, immigration, integration, and security as a way of facilitating coalitions with Far Right parties. Bale (2003) concurs with this diagnosis, indicating that the Centre Right turned Far Right parties into coalition partners and in the process legitimised the latter and their agendas. A clear example of this process can be seen in the political party led by Pim Fortuyn in The Netherlands, which managed to reconstruct the nation's political agenda by pushing certain themes - such as the management of asylum applications - which other parties had long shunned. This turn allowed Fortuyn's party to pass itself off as a respectable party in Dutch society (a nation with a long tradition of progressive thinking and tolerance) (Van der Brug and Mughan, 2007).

For many years, Spain was unscathed by this political trend. There were several reasons for this, the two main ones being: (1) Spain's Far Right had strong links with and hankerings after the Franco dictatorship; (2) the Partido Popular's monopoly of the electoral space in which a Far Right party might otherwise hope to find voters (that is to say, a Central Right party PP - commanded the loyalty of potential Far Right supporters) (Hernández Carr, 2011). Thus the two biggest Far Right Spanish parties - Fuerza Nueva, and Falange Española de las JONS — made no impact whatsoever on the nation's institutions (Rodríguez Jiménez, 2012). The Far Right contagion eventually reached Spain from the rest of Europe but it occurred in municipal politics, examples being parties such as Democracia Nacional, España 2000, and Plataforma per Catalunya, which have drawn up electoral strategies based on issues such as immigration and criticism of the establishment, mirroring approaches taken by the Far Right elsewhere in Europe (Sánchez Duarte and Rodríguez Esperanza, 2013; Rodríguez Jiménez, 2012). The Far Right in Spain saw the opportunity to go beyond local politics, with Vox racking up victories in the Andalusian Regional Election held in December 
2018. Here, Vox played a key role in the formation of a Conservative alliance, toppling PSOE from the regional government after almost 40 years in power.

\section{JOURNALISTIC COVERAGE OF THE ELECTION CAMPAIGN}

The media play a key role in the way citizens' access political information - a role that becomes all the more important during election campaigns (Esser and D'Angelo, 2006). Even so, research on journalistic coverage of politics reveals a mainly media-based approach that makes it hard to foster critical public views on subjects of general concern (Cappella and Jamieson, 1996; Trimble and Sampert, 2004). By contrast, the media facilitate a reading of the campaign in two ways. On the one hand, a campaign is presented as a game or competition between the parties taking part, which implies that the narration is framed in terms of winners and losers - often based on the scenarios painted by opinion polls (Aalberg, Strömback, and De Vreese, 2011). On the other hand, information on the parties in the campaign usually focuses on their strategies more than their manifesto promises, on their attacks on their opponents, and on their leadership styles (Valentino, Beckmann and Buhr, 2001; De Vreese and Semetko, 2002).

Yet research on campaigns is also covered: (1) the relative weights given to campaign subjects; (2) the policies parties put in their manifestos (which should be central to the pre-election debate but which are usually overlooked). Other studies (Valera Ordaz, Carratalá and Palau Sampio, 2017) have approached research on political communication in campaigns by considering parties as mobilising agents, seeking to place their messages in diagnostic and prognostic frames of reference (especially the latter) (Entman, 1993) - something that is characteristic of social organisations seeking to spark collective action (Benford and Snow, 2000). In any event, recent studies on political parties' communication find that their discourses have also been shaped by the media. Thus media-created frames have played a hegemonic role, with campaign coverage strongly influencing the way parties put over their proposals to the electorate
(Palau Sampio, Carratalá and Valera Ordaz, 2017). This process is a clear example of mediatisation (Strömback, 2008; Mazzoleni and Schulz, 1999).

\section{METHODOLOGY}

This study focuses on analysis of the three main RightWing parties taking part in the Valencian Regional Election held on the $28^{\text {th }}$ of April 2019 - Partido Popular, Ciudadanos, and Vox - and their public discourses in a context where they were rivals yet also potential coalition partners in a new government.

We drew on coverage by The Valencian Country's two main newspapers - Levante-EMV and Las Provincias - to get an idea of the political discourse of all three parties during the campaign. We took this approach after ruling out using messages published on the parties' web sites. This was because neither Ciudadanos nor the Vox web sites contained worthwhile updates. The respective readerships of the two newspapers were 197,000 and 101,000, as estimated by Estudios General de Medios (Media Studies group) in its second 2019 edition. The period analysed covered the two weeks of the election campaign. Specifically, we reviewed both newspapers' coverage of the Right-Wing parties from Saturday the $13^{\text {th }}$ of April (the day before the campaign began) to Saturday the $27^{\text {th }}$ of April (the day after it ended). One should note that there were no newspapers on the $19^{\text {th }}$ of April - Good Friday something that is traditionally the case in Spain. We therefore confined the analysis to 14 days (that is to say, 28 newspaper issues in all).

The 'run-of-the-mill' journalistic coverage found in election campaigns included at least one article a day on the main parties and the campaign events they had held. There was not an article on any given party every single day. On a given day, there might be no article on one or more parties, and on others more than one article. In total, we compiled 77 units of analysis, covering news, reports, and interviews. Twenty-nine of these were from Levante-EMV newspaper and the other forty-eight were from Las Provincias (Table 1). The 
difference in number of articles taken from the two newspapers is explained by the fact that Levante-EMV practically gave no coverage of Vox (save for a report of the $26^{\text {th }}$ of April, on the party's main rally in The City of Valencia). Meanwhile, Las Provincias had much more coverage of Vox, with no fewer than 14 articles.

Table 1 Corpus Composition

\begin{tabular}{|c|c|c|c|}
\hline & $\begin{array}{c}\text { Levante- } \\
\text { EMV }\end{array}$ & $\begin{array}{c}\text { Las } \\
\text { Provincias }\end{array}$ & Total \\
\hline $\begin{array}{l}\text { Partido } \\
\text { Popular }\end{array}$ & 15 & 18 & 33 \\
\hline Ciudadanos & 13 & 16 & 29 \\
\hline Vox & 1 & 14 & 15 \\
\hline Total & 29 & 48 & 77 \\
\hline
\end{tabular}

Source: The Authors

Our study tested four hypotheses covering the analysis of the materials. First, as was confirmed by earlier studies (Valentino, Beckmann and Buhr, 2001; De Vreese and Semetko, 2002) and bearing in mind the three parties' competition for the same electorate, we hypothesised that:

H1: The main frame for information on the RightWing parties was of a strategic nature and was linked to leadership style, given each party's need to position itself as the first choice for this part of the political spectrum.

Second, as we showed in the study on the impact of Far-Right parties in the rest of Europe, most of the Centre-Right parties ended up incorporating themes highlighted by Far-Right parties in their discourses, such as immigration and public safety (Bale, 2003; Van der Brug and Mughan, 2007). We envisaged that:

H2: The themes stressed by Far-Right European parties over the last few years would predominate in coverage on Vox, even though they would also be present in news on PP and Cs.
Banging the drum of anti-Catalanism paid handsome electoral dividends for Valencia's Right-Wing during Spain's painful transition from dictatorship to democracy in the late 1970s and in the 1980s (Sanz, 1982; Flor, 2010). Furthermore, some recent studies (Ridaura Martínez, 2016) reveal that rejection of independence-seeking nationalism has been a leitmotiv in Valencian Country elections from the moment that Catalan independence began to dominate the Spanish news scene. Taking both these things into account, it is reasonable to think that:

H3: Conservative parties would exploit the supposed 'pan-Catalanist threat', fully aware of the symbolic legacy of the so-called 'Battle of Valencia', and how Catalonia's independence process could be weaponised and to garner votes.

Last, in the campaign context, the most likely postelection scenario (according to the polls) was one of a pact among the Centre-Right parties. The reason was that such an accord offered the only option of forming a Right-Wing government. This suggested that the coverage of these parties would be based on a strategy of political bipolarisation - something already seen in other European countries with the growth of the Far-Right (De Lange, 2012). Accordingly, we hypothesised that:

H4: Right-Wing parties will set clearer limits among themselves regarding the Left, except Vox, which will also attack Partido Popular and Ciudadanos because it needs to gain its first ever seats in the Valencian Parliament.

To test these hypotheses, the 77 items making up the corpus were analysed using combined quantitative and qualitative techniques. Identification of the framing of the information on these parties was based on analysis of the headlines - an approach that has already proven useful in other studies (Palau Sampio et al., 2017; Carratalá and Palau Sampio, 2019), which distinguished three frames, namely: political dynamics (manifestos); mediatisation (tactics, strategy); collective action (forecast). 
With regard to the other dimensions (themes, cultural resonance, identities), we took all of the journalistic text into account because this let us identify some of the key elements in greater detail. We considered six topics to discover the themes tackled in the election coverage of the three Conservative parties in our study. These topics were ones that recent studies had suggested as being of key importance in the European Far-Right's political discourse, to wit: (1) immigration; (2) gender/equality; (3) the elites; (4) security; (5) identity; (6) the economy/Welfare State (Hernández Carr, 2011; Krasteva and Lazaridis, 2016; Mayer, Šori and Sauer 2016; Staykova, Otova and Ivanova, 2016). Quantitative analysis was used to both identify: (1) the preferred frames used in headlines for each of the units making up the corpus; (2) the formulas parties employed in presenting and questioning other parties. This approach furnished data on both the presence and frequency of the phenomena studied.

In a complementary fashion, we applied qualitative techniques of our own to the discourse analysis. Such an approach has proved fruitful in recent research on the discourse of Europe's Far Right (Sauer and Pingaud, 2016), allowing examination of cultural resonances (Gamson, 1988), and reconstruction of each party's ideological framework. One should note that this framework reveals the party's self-image and how it projects itself to the electorate, highlighting the party's virtues and downplaying its vices (while doing precisely the opposite in characterising other parties) (Van Dijk and Rodrigo Mendizábal, 1999). Such a framework fosters political polarisation which, as we have seen, is growing throughout Europe.

\section{RESULTS}

The results are set out in four sections, one for each of the four research hypotheses. The first describes the data gleaned from the quantitative analysis of the main frames for the examined headlines. The second quantitatively studies the themes appearing in the information. The presence of these themes is

Figure 1 The main frames in coverage of Central-Right parties (in \%)

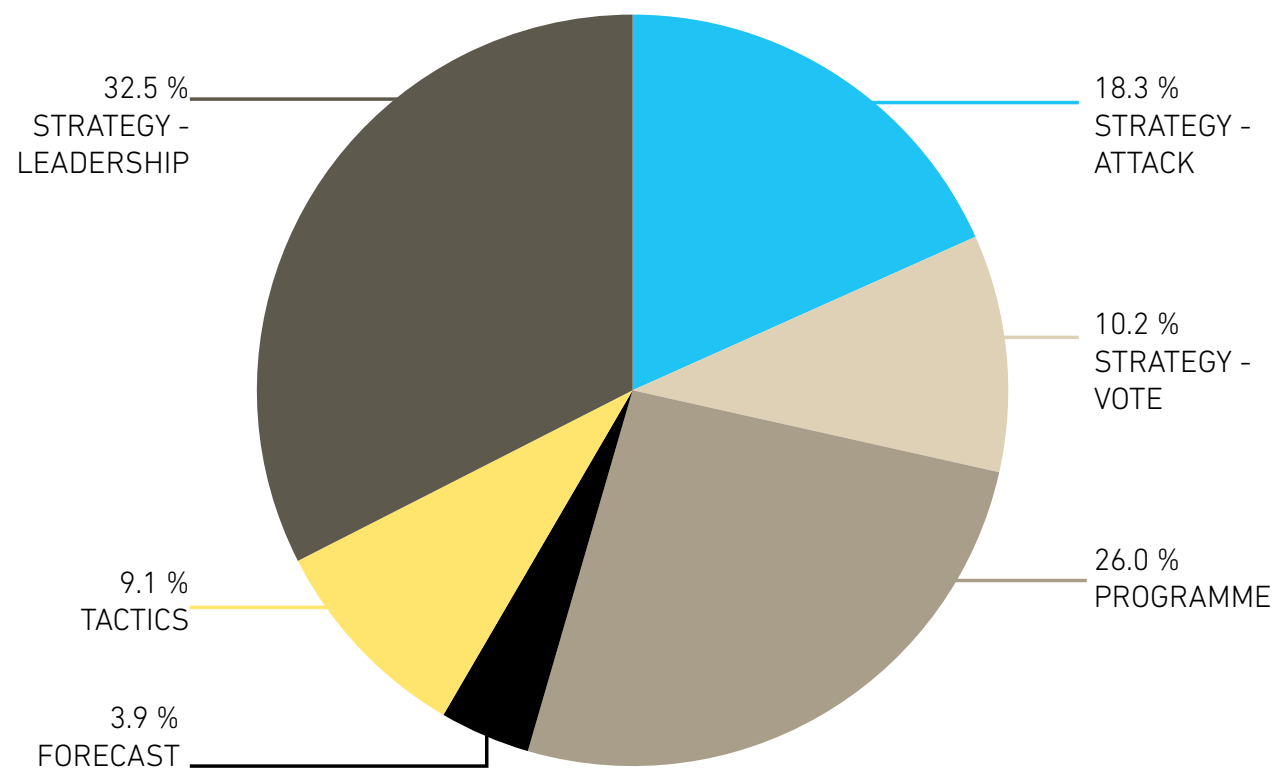


analysed, depending which of the three parties is the protagonist of the news report. The third sets out observations bearing on the symbolic incorporation of 'The Battle of Valencia' in the present electoral discourse of the three parties. The fourth and last section sets out the observations bearing on the present electoral discourses of the three parties to identify each party's political communication throughout the campaign.

\section{Preferred frames}

The dominant frame for information on Right-Wing parties during the campaign was the strategic nature of six out of the ten items analysed. As Figure 1 shows, the frame bearing on leadership styles pre- dominated, underlining how important strategies for wielding power, and candidates' attitudes and their behaviour can affect future management: "Bonig: "We are the only party that has a head on its shoulders. Our management shows we are up to the job" (LE, 27/04/2019); "Does the Catalan conflict worry The Valencian Country?" (LE, 16/04/2019); and "Vox's leader is the caped crusader" (LP, 15/04/2019).

Issues linked to leadership style cropped up in almost a third of the reports published during the election campaign, especially in those protagonised by PP (44\%), whereas both Cs and Vox made up 28\%, as can be seen in Figure 2. Within the strategy frame,

Figure 2 Main frame, depending on the party protagonising the report

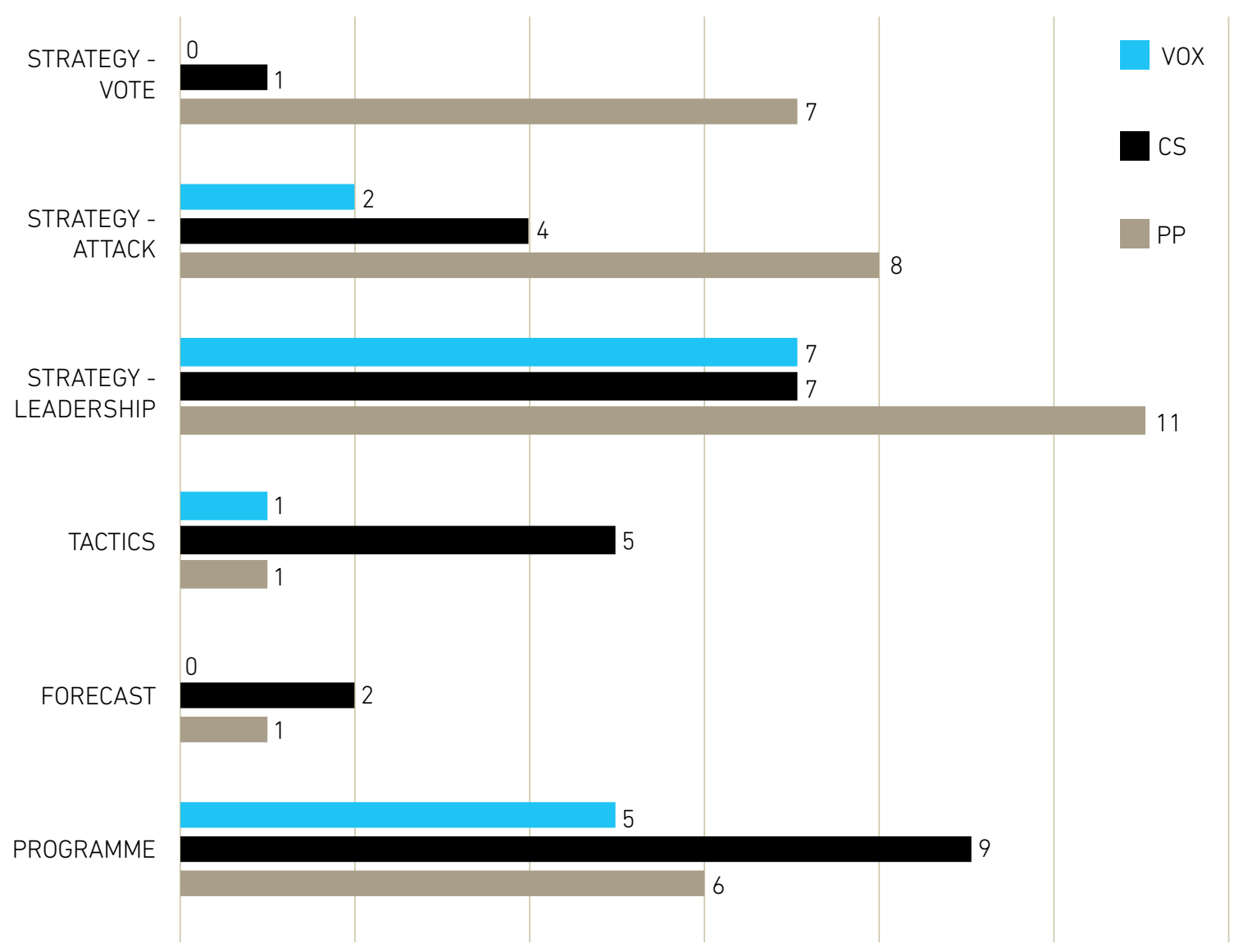


Figure 3 Main frame, depending on the communication medium

LAS PROVINCIAS

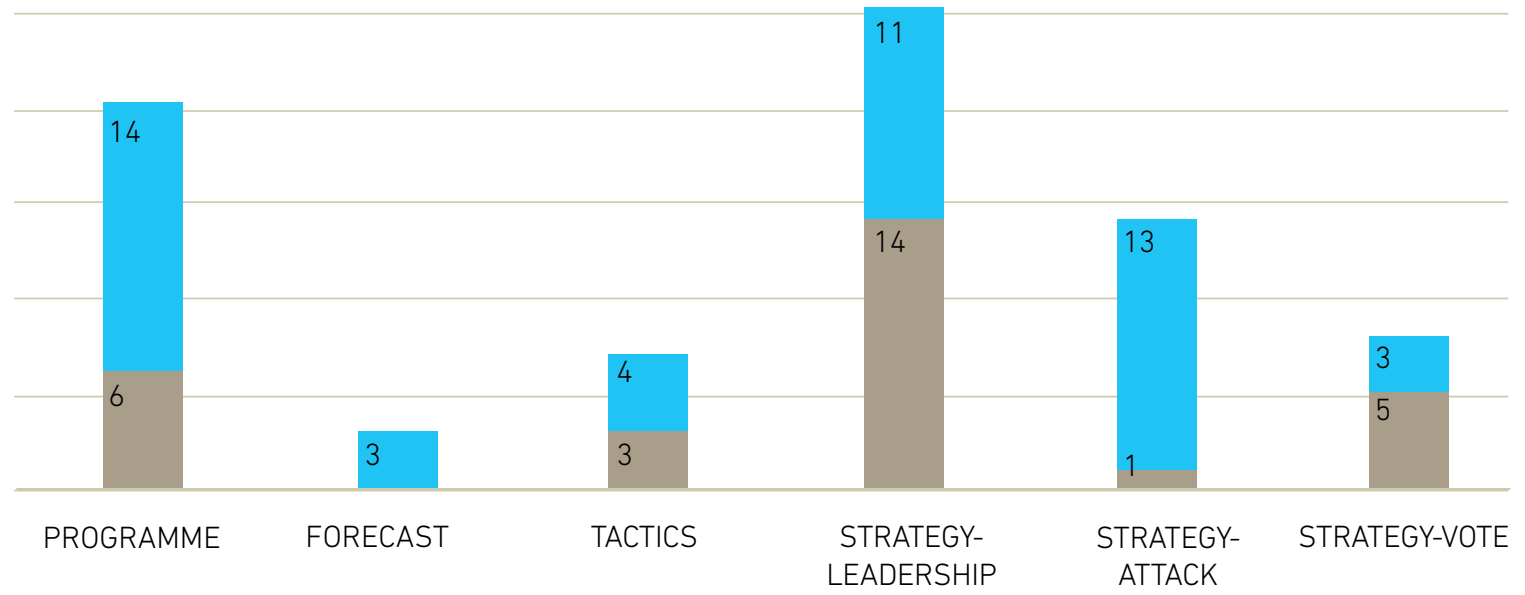

Source: The Authors. attacking a rival featured in $18 \%$ of the news reports. Here, reports protagonised by PP made up over half of these items (57\%), with examples such as: "PP criticised Puig's 'cowardice' for refusing a one-toone debate with Bonig" (LP, 16/04/2019) and "PP lashes out against Catalanist education of Valencian children" (LP, 21/04/2019). Here, one should note that most of the reports falling within this frame were published in the pages of Las Provincias. This newspaper also published reports on Vox (14.5\% in this frame): "Vox: Rajoy "had to resign" and left it to Sánchez" (LP, 25/04/2019), and on Cs (28.5\% in this frame): "Cantó slates The Botanic Pact for failing to put an end to school huts" (LP, 16/04/2019). By contrast, Levante-EMV only carried one report of an attack on another party, as can be seen in Figure 3.

The strategic frame for voting implies a direct appeal for support or for tactical voting, the latter being an option that appeared in one in ten reports published during the campaign by The City of Valencia's two main newspapers. As in the previous section, PP was the party that again stood out. In fact, it featured in no less than $87.5 \%$ of the reports falling within this frame, and in particular in those featuring the party leader for the whole of Spain (Pablo Casado), with a key message to stop the other two Right-Wing parties (Cs and Vox) from taking PP's electoral turf: "Casado tries to lessen PP's electoral losses by asking Right-Wing voters to concentrate their votes in his party" (LE, 21/04/2019), "Casado calls on the electorate to vote for PP instead of for unreliable, pop-up parties" (LP, 26/04/2019), "Casado demands the vote to stop political fragmentation of the Right-Wing" (LE, 27/04/2019).

The programme frame, which was linked to party manifesto proposals, accounted for $26 \%$ of the reports analysed. Reports on Cs predominated in this frame, making up almost half of all reports (45\%), followed by Partido Popular (30\%) and Vox (25\%). These proposals included news items highlighting the measures on which the party would legislate - "Cs plans a law to stop favouritism in the awarding of public contracts" 
Figure 4 The predominant frame during the first and second weeks of the campaign

$1^{\text {ST WEEK }}$

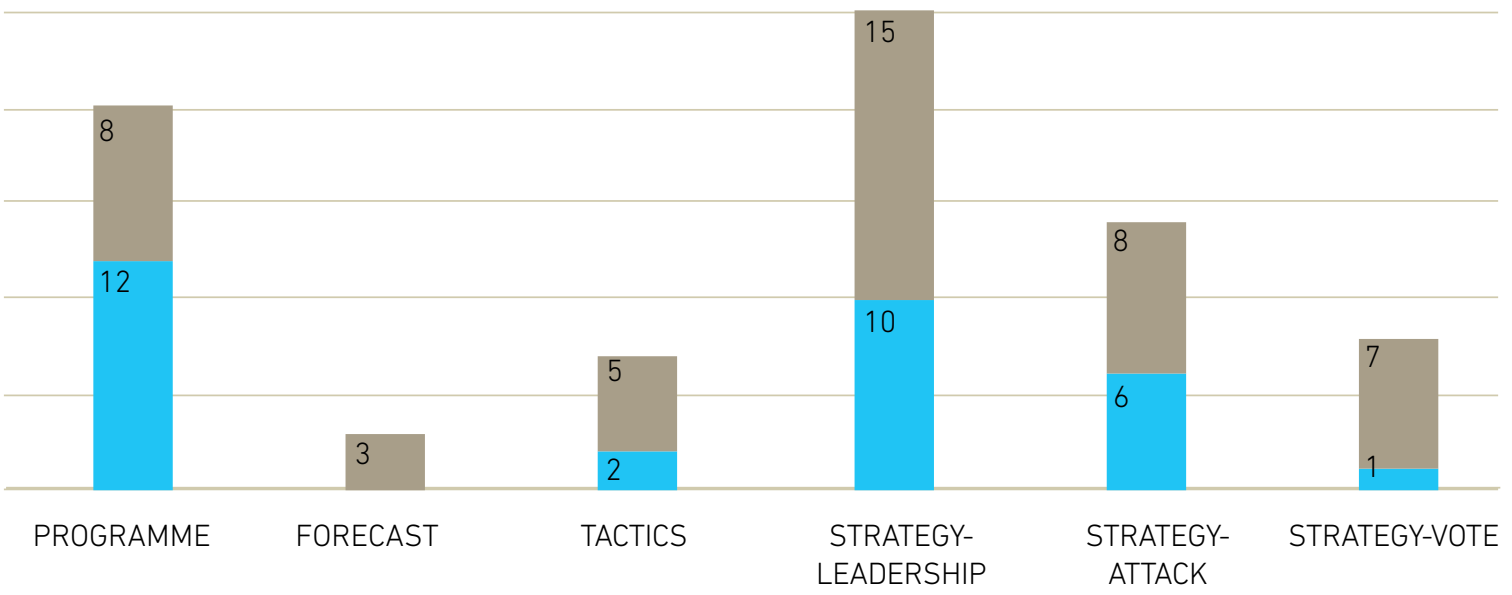

Source: The Authors.

(LE, 23/04/2019); "Bonig announces plans for a law to give tax breaks to those looking after the home" (LP, 13/04/2019) - and proposals they would act upon if they got into government - "Cantó makes plans to keep school canteens open the whole year round" (LP, 17/04/2019) — or highlighting manifesto points: "Montáñez promises his party will not lower taxes but rather axe 24,000 million in spending" (LP, 17/04/2019). As in the case of the attack-strategy frame, seven out of every ten of the items appeared in Las Provincias newspaper.

The tactics frame accounted for $9.1 \%$ of the newspaper reports - a lower figure than that found in other studies. The frame was shaped by the way the campaign battle unfolded, and by support and possible alliances. Cs clearly led in these reports. In an election that was an open field and without any one party capable of winning an absolute majority, the frame was dominated by discussion of potential pacts: "Arrimadas offers an alliance with PP"' (LE, 21/04/2019) and "Cantó insists that he will not ally with Puig even if Rivera asks him to do so" (LP, 13/04/2019). By contrast, the forecast frame (which included symbolic references to the main themes of the political debate and the action plan) cropped up little in the sample (3.8\%) and was linked to Cs and PP.

As can be seen in Figure 4, the strategy frames strongly stood out during the second week of the campaign (almost double that in the first few days), while the news items linked to the programme were the only ones carrying more weight during the first week.

\section{Dominant themes}

Examination of the themes dealt with in each of the analytical units (the same article might deal with more than one matter) revealed that PP, Ciudadanos, and Vox stressed the usual subjects found in Conservative discourses but without highlighting the topics the European Far Right has made its own over the last few years. Thus, as can be seen in Figure 5, two subjects that took pride of place were identity ( $47 \%$ of the units analysed) and the economy/The Welfare State, 
Figure 5 Themes in which a given party mainly featured in connection with an accord

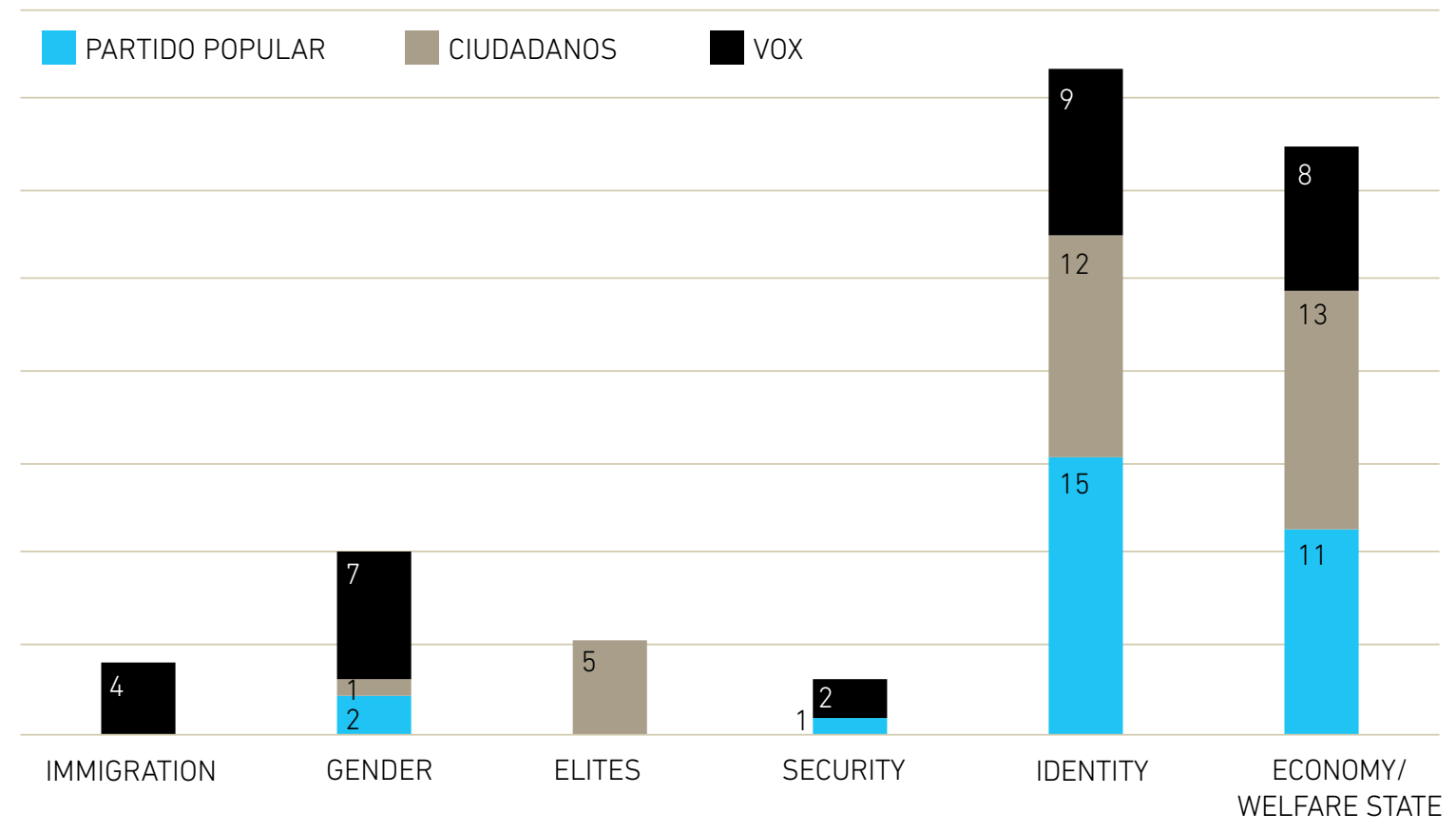

Source: The Authors.

which appeared in $42 \%$ of cases. The identity theme was especially important in news on Vox (60\% of news on Vox), and less so for PP (45\%) and Cs (41\%).

Nevertheless, there are some differences in the way each party tackles the identity issue. Vox pushes the theme by stressing its Spanish nature through its explicit affirmation of loyalty to Spain (LE, 26/04/2019) and more subtly, through its references to bull-fighting (LP, 15/04/2019). Language also plays a key role in how Conservative parties tackle the identity issue. Thus Cs constantly harps on the theme of the Valencian language (a member of the Catalan 'family') being imposed on Castilian speakers, especially in schools: "There are 205 nursery schools in which children are not taught for a single hour in Spanish" (LE, 16/04/2019). On other occasions, identity seems to be linked to the unique features of Valencian and the supposed threat posed by Catalan to The Valencian Country's traditions - a tack often taken by PP: "Bonig promises to re-enact the Act on Symbols of Valencia's Identity" (LP, 20/04/2019).

The economy and The Welfare State ranked second as themes. Vox, once again, was the party that stood out, using these arguments most often (53\%), followed by Cs (45\%) and PP (33\%). In general, two messages were put across. One was the need to cut taxes (given that these parties think Valencians are overburdened by taxation). Vox sought "a major cut in taxes" (LP, 13/04/2019). So did Cs: "We are drowning in taxes" - a reference to the tax burden borne by small businesses (LP, 18/04/2019). On the same lines, PP promised that if it won, there would 
be "a huge fall in taxes, including the scrapping of death duties and taxation on donations and wealth" (LP, 23/04/2019). Another well-worn theme was the link between the economy and The Welfare State, specifically the latter's institutional structure and the expenses it involved - an argument that was virtually monopolised by Vox, which argued the need for "absolute austerity" and that "public administration needed to be a lot smaller" (LP, 13/04/2019), "Spain needs a radical overhaul of its public administration" (LP, 21/04/2019), and "dismantling of the regional government system because it is so wasteful" (LE, $26 / 04 / 2019$ ), these being just some examples of this line of reasoning.

The other themes found in Far Right election rhetoric were less evident and were linked to Vox's public discourse. This was the only party tackling the subject of immigration, even though it only made up one out of every four items (27\%), for example, when the party referred to "the growing Muslim invasion as a result of Europe's wrong-headed frontier control policies" (LP, 13/04/2019). Vox also referred to public safety in its campaign, speaking of Spaniards "right to selfdefence" (LP, 13/04/2019; LP, 26/04/2019). PP also spoke on public safety, albeit to a lesser extent, when it alluded to reviewable life sentencing (LP, 18/04/2019). On the issue of gender equality, all three parties raised the theme but only Vox did so often (47\%), arguing the need to abolish the LGTBI Act (LP, 13/04/2019) and 'gender violence' legislation (LP, 21/04/2019), denouncing that the latter "tells our children which sex they ought to be"" (LP, 25/04/2019). PP and Cs, by contrast, defended gender equality at one moment or another, and some of its representatives called themselves feminists, such as the PP's Belén Hoyo: “I am a feminist because I believe that feminism is the battle for equality between men and women" (LE, 18/04/2019). Last, with regard to the elites and the establishment, our analysis revealed that only Ciudadanos mentioned the subject (17\%), in connection with journalistic coverage on the party's defence of a Public Administration "with fewer politicians and hangers-on" (LE, 14/04/2019). The party proposed an "anti-corruption law" stipulating that public contracts would be awarded on the basis of merit and that "showing one's Compromís or Valencian PSC party card would not be enough to clinch a contract" (LE, 23/04/2019). It also stressed that politics is often far removed from society's concerns (LE, 24/04/2019).

\section{Recovery of identity symbols in the electoral battle}

Our analysis of the two newspapers' coverage of the three right-wing parties during the election campaign shows that references to national identity and symbols were strongly present, with echoes of the so-called 'Battle of Valencia' several decades earlier. Incendiary allusions to 'the Catalan threat' and the imposition of a language other than Castilian were tossed around with the same wild abandon in the 1990s as had the Blaverists' Molotov Cocktails a decade and a half earlier. These ideas were key to the victory of Unión Valenciana, the heir of Blaverism. Exactly the same arguments resurfaced in the 2019 Regional Election in the context of a fierce battle for right-wing votes among the three parties. This cultural echo came over loud and clear in almost a third (32.4\%) of the items analysed, this time with PP and Cs playing the role of political arsonists.

The situation stemming from Catalonia's frustrated 'independence process' provided the pretext for dusting off the spectre of Catalanism - "Cs is worried about the Catalan conflict in The Valencian Country" (LE, 16/04/2019) - in all its diverse forms, including linguistic aspects" [that is, questioning the unity of the language and its (supposed) 'Pan-Catalanist expansion'] (LP, 13/04/2019). This thesis was especially marked in PP's discourse. Bonig stated that nationalism "seeks to annex this land" (LE, 27/04/2019) and Casado spoke of taking action so that "The Valencian Country does not end up as an appendage of The Catalan Lands" (LE, 27/04/2019), arguing that the regional government which emerged from The Botanic Pact was seeking to turn The Valencian Country into a 'colony' of Catalonia (LE, 23/04/2019) and Valencians into "second-class Catalan citizens" (LP, 23/04/2019). Such fiery statements were more common during the middle and the end of the campaign. Following the same line, Vox dragged the discourse towards the ground of 
Spanish nationalism - "We shall act strongly for Spain and for The Kingdom of Valencia" (LP, 25/04/2019), stressing the party's wish to be "loyal to Spain and never to The Valencian Country" (LE, 26/04/2019).

Catalanism was presented as "a real threat" by the Vox leader in The Valencian Country in an interview (LP, 13/04/2019). A PP candidate spoke of "a real risk" (LP, 14/04/2019). Metaphors on the same lines rained thick and fast, with Catalan nationalism being characterised as "a threatening plague" (LP, 13/04/2019) and arguing the need to "stop it spreading like the 'flu in The Valencian Country after four years of the tripartite government" (LP and LE, 21/04/2019), as Cs' leaders put it. The party's leader in the Valencian Region spoke of ideological imposition (LE, 22/04/2019) that used "school classrooms to advance Catalanism in Valencia" (LE, 24/04/2019), an argument that PP also used, stating that the party would fight "to ensure that nobody brain-washes Valencian children through Pan-Catalanist education" (LP, 21/04/2019).

\section{The ideological frame of Valencia's right-wing}

First, one should note that the newspapers analysed almost always referred to the political parties by their official names, save on a few exceptions. The only 11 cases alluding to Centre-Right parties without using the official name are concentrated in references to Ciudadanos and to Vox. In most cases, however, this does not imply an ideological or political characterisation of the party but rather just offers stylistic variety by resorting to expressions such as "the orange party" (LE, 14/04/2019; LP, 22/04/2019) (LE, 23/04/2019; LP, 23/04/2019), in the case of Ciudadanos, or "the party led by Abascal" (LP, 17/04/2019; LP, 22/04/2019) (LP, 18/04/2019), in the case of Vox. The only case in which a newspaper ideologically labelled a party occurred in a news item in Levante-EMV in which the paper referred to Vox as the "Far-Right party" (LE, 26/04/2019).

Thus name-calling based on one or other attributes fell to the parties themselves during the election campaign. Here, it is worth noting how each of these three parties used the campaign to define itself and thus delimit the 'us' that it wished to identify in its mobilisation of voters. Analysis of the news indicated that this discursive effort strongly shaped PP's public utterances (70\% of the items included self-definitions of the party). It was followed by Vox (40\%), and by Ciudadanos (17\%), the last being least interested in defining itself through its electoral messages. By contrast, PP often adopted this approach, especially to stress its experience in running institutions - a common idea in the framing of PP campaigns (Valera Ordaz et al., 2017) and that Bonig repeated endlessly in interviews, of which the one published in Las Provincias on the $23^{\text {rd }}$ of April was just one more example ("We can be relied upon. We are the party of management and we have shown our mettle by twice getting Spain out of a crisis"), as well as at election rallies: "This party has a head on its shoulders and its management proves it" (LE, 27/04/2019). Vox, in contrast, opted to put itself over as a courageous, rising force with which ordinary people could identify: "Our voice is strong, clear, firm and proudly represents the Spaniards who work and pay their taxes" (LP, 14/04/2019) and "We are here to change politics and to render true public service" (LP, 16/04/2019).

In addition to defining "us", the parties also spent much of their campaign discourse on identifying "others" - which is to say their political opponents. Logically, on many occasions all three Centre-Right parties set themselves apart from the Left, which they usually referred to as "The Tripartite Coalition", "The Botanic Pact", "The Sánchez Coalition" (a formula often used by Bonig to refer to the PSPV-Compromís Government) or "The Valencian PSC" (the expression used by Cantó). These references to the Left (as one would expect) were always unflattering and were found in $73 \%$ of the news in which PP was the protagonist, in $62 \%$ of items bearing on Cs, and in only three items on Vox.

Nevertheless, one should note how Centre-Right parties construct "others" based on one of the parties with which they share an electoral niche. This discursive operation can be seen in many of 
the items examined. It is present in news on the parties in $45 \%$ of the items on PP and Cs, and in $40 \%$ of the items on Vox. In Partido Popular's case, the party most commonly referred to Cs and Vox, which occurred in 10 items: "A vote for Vox could end up being a vote for Pedro Sánchez. A vote for Ciudadanos could be a vote for anyone because they are a bunch of turncoats - one never knows which way they will jump" (LP, 14/04/2019) and "The 'orange' brigade is holding the candle but 'The Greens' are holding a gun" (LP, 23/04/2019). Sometimes the reference was only to Cs, as was the case with five news items, where they were defined as "the political hinge" (LP, 24/04/2019) or as a party willing to form an alliance with the Socialists (LE, 20/04/2019; LP, 23/04/2019).

Ciudadanos, focused on PP as the benchmark RightWing party - as can be seen in nine items in which it went so far as to identify PP with PSOE: "It is hard to strike a deal with PSOE or PP because they are parties that have always given ground to nationalism" (LE, 22/04/2019) - or underlined PP's links with corruption - "PP besmirched the Valencian Region's good name, they stole from us and racked up unbearable debt" (LP, 13/04/2019). C's also alluded to PP and Vox in ways to put voters for those parties on the spot rather than the parties themselves: "I can understand Vox voters because they are angry, tired, and fed up with the political class but they should realise that there is another Centre-Right Wing option they can vote for" (LP, 22/04/2019); "I grasp the anger of many Vox voters because they were betrayed by the PP, which robbed them blind, mismanaged our money, and besmirched the Valencian Community's image" (LP, 24/04/2019).

On the other hand, Vox regularly alluded only to the $\mathrm{PP}$ - "Voting for them is sticking with a Welfare State for the political class and its corruption and hypocrisy" (LP, 13/04/2019) and to a lesser extent, it labelled PP and Cs as: "The Cowardly Right", "They haven't an ounce of courage"", "The "orange' Right" and "Quo Vadis? Which way is the wind blowing today? What do the polls say?" (LP, 26/04/2019).
Only on five occasions did the Centre-Right parties seem to tone down their political arguments and try to forge a political bloc featuring two or three parties under the banner of a common "us". This was especially true in the closing stages of the campaign and the main party taking this tack was Ciudadanos. An instance of this was Arrimadas during a rally in Valencia - "I hold out my hand to PP... and ask Pablo Casado to buck up and start thinking about how he can join us to throw out Sánchez" (LE, 21/04/2019). Another was Cantó, who in an interview praised the pact reached in Andalusia: "I hope I do not have to strike a deal with a party other than PP so that we can come up with an Andalusian-style pact" (LE, 22/04/2019).

\section{DISCUSSION AND CONCLUSIONS}

The results from our analysis lead us to conclude that the election discourses of the three main Valencian Centre-Right parties in the Regional Election were shaped by strong competition and, to a lesser extent, the scope for a future alliance. This scenario seems to have had a much more direct impact on the way Partido Popular and Vox framed their public messages during the 15-day campaign, as the coverage of the two newspapers in our study shows.

As with findings in many earlier studies, journalistic coverage of this campaign gave priority to the media framing of issues, which were present in up to $70 \%$ of the units of analysis making up our sample. Specifically, the strategic frame dominating news treatment of the three parties in our study was the leadership style of the candidates, corroborating our first research hypothesis. The urge to show leadership in the election message stood out in the information on PP and this was likely due to: (1) the party's need to challenge the Left-Wing government and, (2) the polls cast doubt on the PP's hegemony on the Right for the first time in decades. This would also explain the stress the party put on tactical voting, appealing to voters to cast their votes for PP to avoid dispersion of the Right-Wing vote among three parties — something 
that would only boost the chances of the Left-Wing parties forming another coalition government.

With regard to the themes found in the information we analysed, one can say that the subjects most strongly pushed by Europe's Far-Right over recent years have still not made much of an impact on the message put over by Valencia's Centre-Right parties. That said, news on Vox (a Far-Right party) clearly referred to immigration and gender equality issues. Our second hypothesis is therefore only partially confirmed. The most repeated themes (identity, and economy/The Welfare State) cropped up frequently in news on Vox, although they were also important in news on the other two parties. In this respect, despite PP and Cs not having adopted part of the Far-Right discourse on immigration and gender equality, there were similarities in their approaches on economic matters (Vox-Cs) and identity (PP-Vox). They also adopted a similar stance on security. Another significant finding was that one of the themes plugged by Europe's new Far-Right (Hernández Carr, 2011) — the anti-establishment leitmotiv — was only explicitly present in news featuring Ciudadanos, probably because although the party already has several years of political life under its belt, it is still considered an upstart challenging the old two-party monopoly of power. A further explanation is that Ciudadanos has many young professionals in its ranks who are eager to make their mark. This anti-establishment leaning is something that Ciudadano's campaign message had in common with European Far-Right parties.

Our third hypothesis, which covers the weight given to the so-called 'Battle of Valencia' discussed earlier, is only confirmed in the cases of PP and Cs - a theme that we identified in one out of every three items linked to these parties. PP thus resorted to one of the old election ruses used by the Conservative Right in The Valencian Country (Ridaura Martínez, 2016), while Cs drew on its symbolic value because it saw this as in keeping with its firm opposition to Catalan nationalism. In fact, this anti-Catalan stance was one of the principles that led to the founding of Cs, and was likely one of the main reasons why the party has picked up votes in both Catalonia and the rest of Spain over the last few years. As one can see from the results, the warning that Valencian identity was threatened (a discourse ruthlessly exploited by the region's Right-Wingers during Spain's turbulent transition to democracy in the late 70s and early 80s) emerged again in this election thanks to events in Catalonia and discussion of independence from Spain. This anti-Catalanist positioning is supported by newspapers such as Las Provincias, which played a key role in 'The Battle of Valencia'. Over the last few years, the newspaper has been unrelenting in its fierce opposition to and criticism of Catalan nationalism (Xicoy, Perales García and Xambó, 2017). However, the notion of 'the Catalan threat' did not feature in Vox's election message given that use of this rhetoric would suppose defence of Valencia's symbols and traditions - something that would be at odds with the party's Ultra-Spanish Nationalist positioning. Here, one should note that Europe's new Far-Right parties adopt similar stances in their respective countries.

With regard to the ideological framework built by these parties, it is worth highlighting three points. The first is that, unlike PP and Cs, Vox concentrated on constructing 'the other' around the other two competing Right-Wing parties. Thus Vox painted $\mathrm{PP}$ and Cs as more Left-Wing than was the case. The second point is that PP and Vox stressed party characters in their messages to the electorate whereas Cs spent much less effort on this task. This can be seen as a tactic to tempt voters away from their direct competitors. It was thus on this subject that PP and Vox dwelt most in their respective discourses. The third point was that messages showing most willingness to entertain political alliances emanated from Ciudadanos, which despite its criticism of PP, appealed to the latter party to form a common front. At the same time, Ciudadanos showed empathy towards Vox voters though not towards Vox itself, which Ciudadanos practically ignored in its discourses. Our fourth and final hypothesis was thus confirmed, with Vox distancing itself from both PP and Cs, giving Vox an advantage in passing itself off as the true antithesis of 'The Left'. 


\section{BIBLIOGRAPHIC REFERENCES}

Aalberg, T., Strömback, J. and De Vreese, C. H. (2011). The Framing of Politics as Strategy and Game: A Review of Concepts, Operationalizations and Key Findings. Journalism, 13(2), 162-178.

Albert Rodrigo, M. and Hernàndez i Martí, G. M. (2011). La identidad en lucha: Iniciativas civiles culturales ante el conflicto identitario valenciano. Papeles del CEIC, 66, 1-41.

Antón Mellón, J. and Hernández Carr, A. (2016). El crecimiento electoral de la derecha radical populista en Europa: Parámetros ideológicos y motivaciones sociales. Política y Sociedad, 53(1), 17-28.

Bale, T. (2003). Cinderella and her Ugly Sisters: The Mainstream and Extreme Right in Europe's Bipolarising Party Systems. West European Politics, 26(3), 67-90.

Benford, R. D. and Snow, D. A. (2000). Framing Processes and Social Movements: An Overview and Assessment. Annual Review of Sociology, 26, 611-639.

Cappella, J. N. and Jamieson, K. H. (1996). News Frames, Political Cynicism, and Media Cynicism. The Annals of the American Academy of Political and Social Science, 546, 71-84.

Carratalá, A. and Palau Sampio, D. (2019). Entre el activismo y la mediatización: Encuadres de partidos y prensa en la campaña catalana de 2017. Revista de comunicación, 18(2), 73-91.

Cucó, A. (1983). Papers públics. Valencia: Fernando Torres Editor

Cucó, A. (2002). Roig i blau: La transició democràtica valenciana. Valencia: Tàndem Edicions.

De Lange, S. L. (2012). New Alliances: Why Mainstream Parties Govern with Radical Right-wing Populist Parties. Political Studies, 60(4), 899-918.

De Vreese, C. H. and Semetko, H. (2002). Cynical and Engaged: Strategic Campaign Coverage, Public Opinion, and Mobilization in a Referendum. Communication Research, 29(6), 615-641.

Entman, R. (1993). Framing: Toward Clarification of a Fractured Paradigm. Journal of Communication, 43(4), 51-58.

Esser, F. and D'Angelo, P. (2006). Framing the Press and Publicity Process in US, British, and German General Election Campaigns: A Comparative Study of Meta Coverage. The International Journal of Press/Politics, 11(3), 44-66.

Flor, V. (2009). L'Anticatalanisme al País Valencià: Identitat i reproducció social del discurs del "blaverisme" (Doctoral Thesis). Universitat de València, Comunidad Valenciana.

Flor, V. (2010). La instrumentalització mediàtica de la identitat valenciana: El discurs anticatalanista de Las Provincias (1978-1999). Arxius de Sociologia, 23, 113-122.

Gamson, W. A. (1988). Political Discourse and Collective Action. In B. Klandermans, H. Kriesi and S. Tarrow (ed.), From Structure to Action: Social Movement Participation across Cultures (p. 219-244). Greenwich, CT: JAI Press.

Gómez Reino, M. (2009). Las elecciones europeas de 2009 y el espectro de la extrema derecha. Análisis del Real Instituto Elcano, 101, 1-5.

Hernández Carr, A. (2011). La derecha radical populista en Europa: Discurso, electorado y explicaciones. Revista Española de Investigaciones Sociológicas, 136(1), 141-160.

Iranzo, A. (2011). El papel de la prensa diaria durante la transición a la democracia en Valencia (1976-1982) (Doctoral Thesis). Universitat de València, Comunidad Valenciana.

Krasteva, A. and Lazaridis, G. (2016). Far Right: Populist Ideology, 'Othering' and Youth. In M. Ranieri (ed.), Populism, Media and Education: Challenging Discrimination in Contemporary Digital Societies (p. 9-25). Abingdon, New York: Routledge.

Mayer, S., Šori, I. and Sauer, B. (2016). Gendering 'the People': Heteronormativity and 'Ethno-masochism' in the Populist Imaginary. In M. Ranieri (ed.), Populism, Media and Education: Challenging Discrimination in Contemporary Digital Societies (p. 84-104). Abingdon, New York: Routledge.

Mazzoleni, G. and Schulz, W. (1999). “Mediatization» of Politics: A Challenge for Democracy?" Political Communication, 16(3), 247-261.

Meret, S. and Siim, B. (2013). Gender, Populism and Politics of Belonging: Discourses of Right-wing Populist Parties in Denmark, Norway and Austria. In B. Siim and M. Mokre (ed.), Negotiating Gender and Diversity in an Emergent European Public Sphere (p. 78-96). London: Palgrave Macmillan.

Mira, J. F. (1985). Crítica de la nació pura: Sobre el símbols, les fronteres i altres assaigs impetuosos. Valencia: Eliseu Climent. 
Mollà, D. and Mira, E. (1986). De impura natione. Valencia: Eliseu Climent.

Pajnik, M., Fabbro, F. and Kamenova, D. (2016). Ethno-nationalism and Racial Capitalism in Populist Framing of Migrants as a Threat. In M. Ranieri (ed.), Populism, Media and Education: Challenging Discrimination in Contemporary Digital Societies (p. 67-83). Abingdon, New York: Routledge.

Palau Sampio, D., Carratalá, A. and Valera-Ordaz, L. (2017). Mediatización y encuadres de campaña: Análisis comparado de la información de partidos y medios en las elecciones generales de 2015. El profesional de la información, 26(4), 602-610.

Picó, J. and Reig, R. (1988). Crisis final del franquismo y transición a la democracia. In M. Cerdà, (dir.), Historia del pueblo valenciano, III (p. 945-964). Valencia: Levante.

Ridaura Martínez, M. J. (2016). El proceso de independencia de Cataluña: su visión desde la Comunidad Valenciana. Teoría y realidad constitucional, 37, 381-404.

Rodríguez Jiménez, J. L. (2006). De la vieja a la nueva extrema derecha (pasando por la fascinación por el fascismo). Historia Actual Online, 9, 87-99.

Rodríguez Jiménez, J. L. (2012). Historia de un fracaso y ¿de una refundación?: De la vieja a la nueva extrema derecha en España (1975-2012). Studia Historica. Historia Contemporánea, 30, 231-268.

Sánchez Duarte, J. M. and Rodríguez Esperanza, S. (2013). La extrema-derecha en Facebook: España 2000 y Democracia Nacional durante la campaña electoral de 2011. Revista Mediterránea de Comunicación, 4(1), $221-258$.

Sanz, Jesús (1982). La cara secreta de la política valenciana. Valencia: Fernando Torres.

Sauer, B. and Pingaud, E. (2016). Framing Differences: Theorising New Populist Communicative Strategies on the Internet. In M. Ranieri (ed.), Populism, Media and Education: Challenging Discrimination in Contemporary Digital Societies (p. 26-43). Abingdon, New York: Routledge.

Schmitt Beck, R. (2017). The 'Alternative für Deutschland in the electorate': Between Single-issue and Right-wing Populist Party. German Politics, 26(1), 124-148.

Staykova, E., Otova, I. and Ivanova, V. (2016). Anti-elitism as a populist strategy of defending 'the people'. In M. Ranieri (ed.), Populism, Media and Education: Challenging Discrimination in Contemporary Digital Societies (p. 105-123). Abingdon, New York: Routledge.

Strömbäck, J. (2008). Four Phases of Mediatization: An Analysis of the Mediatization of Politics. The International Journal of Press/Politics, 13(3), 228-246.

Trimble, L. and Sampert, S. (2004). Who's in the Game? The Framing of the Canadian Election 2000 by the Globe and Mail and the National Post. Canadian Journal of Political Science / Revue canadienne de science politique, 37(1), 51-71.

Valentino, N., Beckmann, M. and Buhr, T. (2001). A Spiral of Cynicism for Some: The Contingent Effects of Campaign News Frames on Participation and Confidence in Government. Political Communication, 18(4), 347-367.

Valera-Ordaz, L., Carratalá, A. and Palau Sampio, D. (2017). La batalla de los partidos por la definición de la realidad: Los marcos partidistas durante las elecciones generales de 2015. In G. López-García and L. ValeraOrdaz (ed.), Pantallas electorales: El discurso de partidos, medios y ciudadanos en la campaña de 2015 (p. 59-78). Barcelona: Editorial UOC.

Van der Brug, W. and Mughan, A. (2007). Charisma, Leader Effects and Support for Right-wing Populist Parties. Party Politics, 13(1), 29-51.

Van Dijk, T. A. and Rodrigo Mendizábal, I. (1999). Análisis del discurso social y político. Quito: Abya-Yala.

Viadel, F. (2006). No mos fareu catalans: Història inacabada del "blaverisme". Barcelona: L'esfera dels llibres.

Xambó, R. (1995). Dies de premsa. Valencia: L'Eixam Edicions.

Xambó, R. (2001). Comunicació, política i societat: El cas valencià. Valencia: Edicions 3i4.

Xicoy, E., Perales-García, C. and Xambó, R. (2017). Shaping Public Opinion for Confrontation: Catalan Independence Claims as Represented in Spanish, Catalan, Valencian, and Basque Editorials. American Behavioral Scientist, 61(9), 1040-1055. 


\section{BIOGRAPHICAL NOTE}

\section{Adolfo Carratalá}

Carratalá is Professor of Journalism at Universitat de València, and has a Degree in Journalism and a PhD in Communication. Carratalá previously worked as a post-doctoral researcher at Universidad Rey Juan Carlos and as Associate Professor at Universidad Internacional de La Rioja. His main lines of research focus on journalism, on social conflicts, and on LGTBI studies in the media field.

\section{Dolors Palau Sampio}

She is tenured Professor of Journalism at Universitat de València. Palau was awarded a Degree and a PhD in Journalism from Universitat Autònoma de Barcelona (UAB). She has worked at Levante-EMV newspaper for nine years. Her main lines of research focus on journalism quality and on digital and narrative journalism. 


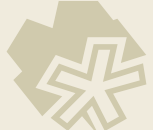

